Article

\title{
The Correlation Level Of Thyroid Stimulating Hormone Andthyroxinewith Spontaneus Abortion
}

\author{
Yellyta Ulsafitri ${ }^{1}$, Rahmatina. B Herman ${ }^{2}$, RosfitaRasyid ${ }^{3}$ \\ ${ }^{I}$ Prodi Magister S2 IlmuKebidananFakultasKedokteranUniversitasAndalas Padang \\ ${ }^{2}$ BagianFisiologi FK Unand \\ ${ }^{3}$ BagianKesehatanMasyarakat FK Unand
}

\begin{tabular}{l}
\hline SUBMISSION TRACK \\
\hline Received : \\
Final Revision: \\
Available Online : \\
KEYWORDS \\
\hline Thyroid Stimulating Hormone, Thyroxine, \\
Abortion \\
CORRESPONDENCE
\end{tabular}

Phone: 082172244920

E-mail: doankyeyen@ymail.com

\begin{abstract}
A B S T R A C T
Abortion is one of the causes of maternal death. The World Health Organization (WHO) estimates that $15-20 \%$ of maternal deaths are caused by abortion. Abnormal level of TSH and T4 during pregnancy will be at risk of abortion because the T4 hormone acts to regulate the body's metabolic processes. The purpose of this study to determine the relationship of TSH and T4 levels in the incidence of abortion.
\end{abstract}

The research design is observational with cross sectional approach which is implemented in regency general hospital of Dr. Rasidin, hospital of Dr. Reksodiwiryo,Bhayangkara hospital, Islam hospital of IbnuSina Padang, and Biomedical Laboratory Faculty of Medicine Andalas University in Padang from September to November 2017. The study population is all pregnant women with gestational age $\leq 20$ weeks with diagnosis of abortion. The sample of research 58 respondents by using consecutive sampling technique Examination of TSH and T4 using ELISA method. Test the normality of data by Kolmogorov Smirnov test. Analysis of comparative data by using Pearson correlation test.

The conclusion of this study are the mean serum TSH level is $2.39 \pm 1.59 \mathrm{mIU} / \mathrm{I}$ and the mean serum T4 level was $8.02 \pm 1.43 \mu \mathrm{g} / \mathrm{dl}$. There is no statistically significant relationship between TSH and T4 levels in aborted event, with $\mathrm{p}=0.07$ ( $\mathrm{p}>0,05)$, with $\mathrm{r}=-0,23$, the relation test is weak, the direction was negative which means more high levels of TSH, the smaller T4 levels in mother abortion

The conclusion, the study proves that, there is no significant correlation between TSH and T4 levels in the incidence of abortion. 


\section{INTRODUCTION}

Maternal Mortality Rate (MMR) is an indicator used to measure maternal health status in a region. Maternal death is death during pregnancy for 42 days of termination pregnancy regardless of duration and delivery due to all causes associated with or aggravated by pregnancy or treatment. ${ }^{1}$ The greatest cause of maternal death in Indonesia in period 2012-2013 there are five namely bleeding, hypertension in pregnancy, infection, long labor or stuck, and abortion. ${ }^{2}$ World Health Organization (WHO) estimated that $15-20 \%$ of maternal death is caused by abortion, 19 million miscarriages occur each year. This miscarriage is close to one miscarriage for every 10 pregnancy, ${ }^{3}$ The number of abortion cases in Southeast Asia was 4.2 million per year, ${ }^{4}$ whereas according to Indonesia Demographic Health Survey (SDKI) maternal mortality rate in 2013 in Indonesia $1.6 \%$ was caused by abortion. ${ }^{5}$

The Annual Report of the West Sumatra Provincial Health Service in 2015 there was an increase in cases of maternal deaths to 17 cases with details of 4 cases of pregnancy, 2 cases of childbirth and 11 cases during childbirth. The cause of death during pregnancy is Spontaneous Abortion. ${ }^{5}$

Abortion was a termination of pregnancy before 20 weeks' gestation or with a fetus having a birth weight of less than 500 grams. ${ }^{6}$ The cause of abortion occurs due to maternal and fetal factors. Fetal factors are caused by abnormalities of zygote development, fetal mudigah, or placenta, while maternal factors may be caused by infection, chronic debility, endocrine disorders, diabetes mellitus, nutrition, drug usage and environmentfactors. ${ }^{7}$ The factor of endocrine changes in the incidence of abortion seems to be related to thyroid hormone deficiency. ${ }^{6}$

Thyroid disorders generally occur in women of reproductive age. The prevalence of thyroid disorders during pregnancy is estimated at 2-3\%. Thyroid disorders can be hyperthyroidism and hypothyroidism. Hyperthyroidism was found to be $0.1-0.4 \%$ of pregnant women and has been associated with pregnancy complications such as miscarriage, pre-eclampsia, abruption of the placenta, impaired fetal growth or premature birth. $^{7}$

Thyroid hormone disorders in pregnant women will cause disruption of blood flow from the mother to the placenta so thatthere is a disruption of fetal growth and development that causes abortion. ${ }^{6}$

Thyroid hormones play a role in the early formation of the placenta stimulating angiogenesis and promoting invasion and differentiation of embryonic cells. T3 thyroid hormone receptors are present on the trophoblast and transport thyroid hormones significantly during pregnancy for fetal growth. ${ }^{8}$ Hypothiroidisme in pregnancy will affect the development of the placenta, because thyroid hormone affects the proliferation and formation of trophoblast cells so that complications will occur to pregnant women such as miscarriage, preeclampsia, and Intra Uterine Growth Restriction (IUGR). ${ }^{9}$ If the thyroid hormone is reduced during pregnancy will result in reduced function of placental trofoblast followed by reduceing endocrine trophoblast function so that there will be an abortion. ${ }^{10}$

Trofoblasts play an important role in the mother and fetus contact. Of all the placenta components trophoblasts have the most varied structures, functions and patterns of development. Provides nutrition to the conception results and serves as an important endocrine organ for maternal physiology adaptation and maintains pregnancy. ${ }^{6}$

thyroid hormone (T4) during pregnancy can lead to increased progesterone, estradiol-17 $\beta$ and $\mathrm{hCG} \alpha$, hCG $\beta$, hCG and hPL by placental tissue and stimulate trophoblast endocrine function. ${ }^{7}$

Abnormal TSH and T4 levels during pregnancy will be at risk for abortion, 
because the $\mathrm{T} 4$ hormone acts to regulate the body's metabolic processes. In the cardiovascular system thyroid hormones play a role in increasing blood flow and cardiac output. ${ }^{8}$ Thyroid hormone disorders in pregnant women will cause disruption of blood flow from the mother to the placenta resulting in disruption of fetal growth and development that causes abortion. ${ }^{9}$

Based on the above, the researchers are interested to conduct research on the relationship between TSH and T4 levels with the incidence of abortion.

\section{METHODS}

The research design is observasional with cross sectional approach. Analysis of comparative data by using Pearson correlation test.This research was conducted in General hospitalof Dr. Rasidin, Hospital of. Reksodiwiryo, Hospital ofBhayangkara and Islamic hospital ofIbnuSina Padang for sampling (serum) and Biomedical Laboratory of Faculty of Medicine Andalas University in Padang for examination of serum TSH and T4 levels from September to November 2017. The population in this study was all pregnant women with gestational age $\leq 20$ weeks with diagnosis of abortion. The sample in this study amounted to 58 people by using consecutive sampling technique. The study materials were blood venous respondent,levels of TSH and T4 are measured

Immunosorbent Assay.

\section{RESULT}

Table 1 Charactheristic of respondents by age, parity, education and occupation

\begin{tabular}{ccc}
\hline \multicolumn{1}{c}{ Risk Factors } & $\mathbf{N}$ & $\mathbf{\%}$ \\
\hline Maternal Age & & \\
$-\quad 20-35$ & 58 & 100,0 \\
$-\quad>35$ & 0 & 0 \\
Parity & & \\
- Primipara & 32 & 55,2 \\
- Multipara & 26 & 44,8 \\
Educational status & & \\
- High & 32 & 55,2 \\
- College & 26 & 44,8 \\
Work & & \\
\hline
\end{tabular}

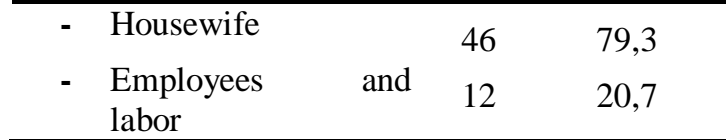

Table 1 gives the details of the characteristics of the respondents in this study. Maternal age during pregnancy is normal, Highest level of parity respondents is primipara highest level of education respondents is high school, and highest level of education respondents is housewife.

Table 2 The Mean Serum TSH and T4 With Spontaneus Abortion

\begin{tabular}{lcc}
\hline \multicolumn{1}{c}{ Variabel } & N & Rerata \pm SD \\
\hline Kadar TSH $(\mathrm{mIU} / \mathrm{I})$ & 58 & $2,39 \pm 1,59 \mathrm{mIU} / \mathrm{I}$ \\
Kadar T4 $(\mu \mathrm{g} / \mathrm{dl})$ & 58 & $8,02 \pm 1,43 \mu \mathrm{g} / \mathrm{dl}$ \\
\hline
\end{tabular}

Table 2 shows that the mean serum level TSH and T4in the mother abortion in normal.

Table 3 TheCorrelation Between TSH and T4 Levels in the Incidence Of Abortion

\begin{tabular}{clc}
\hline Variabel & & Kadar T4 \\
\hline Kadar TSH & $r$ & $-0,232$ \\
& $p$-value & 0,079 \\
\hline
\end{tabular}

Table 3 The results showed that there is no significant relation between Thyroid Stimulating Hormone (TSH) and Thyroxine (T4) on abortion, with $\mathrm{p}=0,079(\mathrm{p}<0,05)$ and $r=-0,232$. Based on the statistical test the strength of the correlation test is weak, the direction is negative which means the higher Thyroid Stimulating Hormone (TSH), the smaller the Thyroxine (T4) in mother abortion.

\section{DISCUSSION}

The Mean Serum TSHWith Spontaneus Abortion

The mean TSH level in the mother's abortion was within the normal range of 2.39 $\pm 1.59 \mathrm{mIU} / \mathrm{I}$. Normal TSH levels in pregnant women Trimester I (TM 1) 0.1 to $2.5 \mathrm{mIU} / 1$, second trimester (TM II) 0.2-3.0 $\mathrm{mIU} / 1$. Thyroid hormones are important in 
the development of the fetus and placenta and maintain maternal well-being. ${ }^{11}$ Human Chorionic Gonadotropin (hCG) plays a role in regulating the thyroid gland during pregnancy which occurs at 10-12 weeks of gestation, because the hCG and TSH hormones have the same alpha receptors and subunits. Thyroid hormone increase is associated withincreasedhCG hormone, resulting in suppression of TSH which causes low TSH levels. When hCG levels are high, hCG will increase thyroid hormone secretion, resulting in negative feedback on the pituitary to suppress TSH release. ${ }^{12}$

The effects of thyroid deficiency in pregnancy are very influential in fetal growth and development. In pregnancy thyroid hormones play a role in the formation of the placenta, where thyroid hormone receptors are found in the trophoblast, if thyroid hormone decreases during pregnancy will result in reduced function of the placental trophoblast followed by reduced function of the endocrine trophoblasts so that abortion will occur. ${ }^{10}$

For the first 10-12 weeks of pregnancy, babies are very dependent on the mother for the production of thyroid hormones. Towards the end of the first trimester, the baby's thyroid begins to produce its own thyroid hormone. However, babies still depend on the mother to ingest sufficient amounts of iodine, which is important for making thyroid hormones. Thyroid hormones are very important for brain development in infants. The effect of maternal hypothyroidism on infant brain development is not very clear. Severe untreated hypothyroidism in the mother can cause brain development disorders in infants. 12

The same research results seen in the study Negro et al. (2010) TSH levels within the normal range of $2.5 \mathrm{mIU} / \mathrm{I}$, do not cause abortion. ${ }^{16}$ In research conductedAndrea et al. (2010), states that TSH levels between 2.5$4.5 \mathrm{mIU} / \mathrm{I}$ are not a sure indication for abortion, other factors such as smoking history, diabetes mellitus, and thyroid peroxidase antibody are considered. ${ }^{17}$
This research is different result seen in the study Karakosta et al. (2011) High TSH levels in pregnant women were 31 respondents. The incidence of subclinical hypothyroidism in pregnant women is estimated to be around 2-3\%. Recent research has shown untreated hypothyroidism during pregnancy to increase the incidence of maternal anemia, preeclampsia, post partum hemorrhage and abortion. ${ }^{18}$ In research conductedBenhadi et al. (2009) abortion can occur in women who have TSH levels <0.34 mIU / I, taking into account other factors such as smoking, parity, age, diabetes mellitus, hypertension, TPA-AB. ${ }^{19}$

\section{The Mean Serum T4With Spontaneus Abortion}

The mean levels of T4 in the mother's abortion were within the normal range of $8.02 \pm 1.43 \mu \mathrm{g} / \mathrm{dl}$. According to the American Thyroid Association (ATA), normal thyroxine levels inpregnant women are 4.5-11.5 $\mu \mathrm{g} / \mathrm{dl}$.Human Chorionic Gonadotropin (hCG) plays a role in regulating the thyroid gland during pregnancy which occurs at $10-12$ weeks of gestation, because the hCG and TSHhormones have the same alpha receptors and subunits. Thyroid hormone increase is associated withincreasedhCG hormone, resulting in suppression of TSH which causes low TSH levels. When hCG levels are high, hCG will increase thyroid hormone secretion, resulting in negative feedback on the pituitary to suppress TSH release. ${ }^{12}$

Thyroxine hormone is the main hormone produced by the thyroid gland (thyroid gland) which affects the body's cell metabolism and regulates body temperature, regulates carbohydrate metabolism, regulates the use of oxygen, carbon dioxide and affects body and mental development. The concentration is at least 25 times that of triiodothyronine (T3). Serum thyroxine levels are generally used to measure the concentration of thyroid hormone and thyroid gland function. ${ }^{18}$

The thyroxine hormone in the fetus is not found at 8-10 mg of pregnancy, therefore 
the fetus needs thyroid hormone from the mother during pregnancy. During the beginning of pregnancy the fetus relies entirely on the thyroid hormone (thyroxine) that passes through the placenta, because fetal thyroid function does not function before $12-14 \mathrm{mg}$ of pregnancy. Thyroxine from the mother is bound to receptors of fetal brain cells, which are then converted intracellularly to fT3 which is an important process for fetal brain development. ${ }^{14}$

Maternal thyroid function during early pregnancy is an important factor for the early development of the fetal brain because the fetal thyroid cannot produce T4 before 12-14 weeks' gestation. ${ }^{25}$ The increased need for thyroxine during the first trimester occurs due to changes in thyroid physiology during normal pregnancy and does not occur in women with hypothyroidism. In healthy women, the total serum thyroxine concentration increases during the first three months of pregnancy and decreases either at the end of the third trimester or earlier. ${ }^{27}$

The thyroxine hormone also plays a role in stimulating the production of $17 \beta$ estradiol and epidermal growth factors to control trophoblast growth and development. The lack of thyroid hormone in the mother during pregnancy will affect placental growth, because thyroid hormones affect the proliferation and formation of trophoblast cells so that complications will occur such as abortion, preeclampsia and IUGR. $^{9}$

Pregnancy affects thyroid function and can cause severe or mild disorders of thyroid deficiency has been associated with obstetric complications such as abortion, preterm labor, gestational hypertension, preeclampsia, and abruption of the placenta.

Maternal thyroid function during early pregnancy is an important factor for the early development of the fetal brain because the fetal thyroid cannot produce T4 before 12-14 weeks of gestation. ${ }^{32}$ The increased need for thyroxine during the first trimester occurs due to changes in thyroid physiology during normal pregnancy and does not occur in women with hypothyroidism. ${ }^{35}$ In healthy women, the total serum thyroxine concentration increases during the first three months of pregnancy and decreases either at the end of the third trimester or earlier. ${ }^{20}$

The same research results seen in the studyBenhadi et al. (2010) there was no significant relationship between $\mathrm{T} 4$ levels and the incidence of abortion. A history of premature labor is another factor that causes abortion. ${ }^{19}$

The CorrelationBetween TSH and T4 Levels in the Incidence Of Abortion

There is no significant relation between Thyroid Stimulating Hormone (TSH) and Thyroxine (T4) on abortion, with $\mathrm{p}=0,079$ $(p<0,05)$ and $r=-0,232$. Based on the statistical test the strength of the correlation test is weak, the direction is negative which means the higher Thyroid Stimulating Hormone (TSH), the smaller the Thyroxine (T4) in mother abortion. This was seen in abortion mothers who had high TSH levels $34.4 \%$ and high T4 levels only $1.7 \%$.

Human Chorionic Gonadotropin (hCG) plays a role in regulating the thyroid gland during pregnancy which occurs at 10-12 weeks of gestation, because the hCG and TSHhormones have the same alpha receptors and subunits. Thyroid hormone increase is associated withincreasedhCG hormone, resulting in suppression of TSH which causes low TSH levels. When hCG levels are high, hCG will increase thyroid hormone secretion, resulting in negative feedback on the pituitary to suppress TSH release. ${ }^{12}$

The cause of abortion is not due to abnormalities in TSH and T4 levels but there are other factors that influence such as a deficiency of the progesterone hormone which can cause uterine relaxation so that it can cause abortion, anemia in the mother which can cause oxygen deficiency so that placental function decreases and causes abortion, chromosomal abnormalities in the mother As $60 \%$ of abortion causes such as autosomal trisomy often seen in first trimester abortion caused by nondisjunction, translocation or inversion of chromosomes, triploidy is associated with hydropic 
degeneration of the placenta, a fetus showing this abnormality often having abortion. ${ }^{15}$

The same research results seen in the studyBenhadi et al. (2010)there was no significant relationship between TSH and T4 levels with the incidence of abortion. This study was conducted on 27 respondents who experienced abortion with a cohort design, the criteria of respondents in this study were mother ages 20 to 35 years, parity $2-3$, no smoking, no hypertension, no diabetes mellitus, and the mother was in good health. The causes of abortion that were not taken into account in this study were respondents who had a history of preterm labor. ${ }^{19}$ In research conductedShiao et al. (2015) there was no significant relationship between TSH and T4 levels with the incidence of abortion. Samples from this study from 79 respondents who experienced abortion, with criteria not having diabetes mellitus, not having hypertension, abortion causes that were not taken into account from this study hypothyroidism that was previously undiagnosed. ${ }^{20}$

This research is different result seen in the studySieiroet al.(2004)there was a significant relationship between TSH and T4 levels with the incidence of abortion with a cohort study design, the sample of this study were 100 pregnant women who were examined for TSH levels (0.4-3.8 mU / 1) and T4 levels $(0.8-2.0 \mathrm{ng} / \mathrm{dl})$ the results of research from 100 samples of 80 samples had imminent abortion and the rest were complete abortion. ${ }^{21}$ In research conductedNambiaret al.(2011)there was a significant relationship between TSH and T4 levels with the incidence of abortion with a cohort study design, the sample of this study were 480 pregnant women who were divided into 7 groups, and 1 group of 272 obtained TSH levels $0.1-2 \mu \mathrm{IU} / \mathrm{mL}$ and did not have thyroid autoimmunity disorders, results obtained 20 samples had imminems abortion, 4 samples experienced infant mortality, 14 samples of preterm birth, and 234 samples of term aterm. ${ }^{22}$ The results of Hirsch et al .(2013) study also found that there was a significant relationship between TSH and T4 levels in the incidence of abortion, the sample in this study was 306 pregnant women, 205 pregnant women had abortion of imminem with TSH levels of 0.36$75.17 \mathrm{mIU} / \mathrm{L}^{23}$

\section{CONCLUSION}

The mean serum TSH level was within the normal range of $2.39 \pm 1.59 \mathrm{mIU} / \mathrm{I}$, the mean serum $\mathrm{T} 4$ level was within the normal range of $8.02 \pm 1.43 \mu \mathrm{g} / \mathrm{dl}$. There was no significant relationship between levels of thyroid stimulating hormone (TSH) and Thyroxine (T4) with the incidence of abortion, with a value of $p=0.079(p>0.05)$ 


\section{REFERENCES}

Dinas Kesehatan Provinsi Sumatera Barat. West Sumatra Province Health Profile 2014. Padang : Dinas Kesehatan Provinsi Sumatera Barat. 2015 : 12 : 1-2.

Lieskusumastuti, AD. Risk Factors Associated with Spontaneous Abortion at PKU MuhammadiyahDelanggu Hospital. Srikpsi.SekolahTinggillmuKesehatanMamba'ul 'Ulum Surakarta. Surakarta.2016.

WHO.Tren in Maternal Mortality 1990 to 2013, Geneva. 2014.

Mahdiyah, D. Rahmawati, D. Lestari, A. Parity Relationship with the incidence of Abortion in the Maternity Room of the RSUD. Dr. H. Moch. Ansari Saleh. Skripsi.SekolahTinggiIlmuKesehatan Bandung. Bandung. 2013.

Kementrian Kesehatan RI.Indonesia's 2012 Demographic and Health Survey. Kementrian Kesehatan RI. 2013: 85-101 : 1-3.

DinasKesehatanProvinsi Sumatera Barat. (2015). 2015 Government Agency Performance Accountability Report.Padang: Dinas Kesehatan Provinsi Sumatera Barat. 2015 : 12-16

Cunningham, FG. Leveno, KJ. Bloom, SL. Spong, CY.Dhase JS. Hoffman, BL et al (2014) William Obstetrics. 24th edition. New York :McGraw Hill Education.2014: 142-162: 4dan10.

Schneuer, FJ. Nassar, N. Tsevski, V. Morris, JM. Roberts CL.Association and Predictive Accuracy of High TSH Serum Levels in First Trimester and Adverse Pregnancy Outcomes.J ClinEndocrinolMetab (JCEM) end ojournals. Vol 97, 2012, pp: 3115-3122

Barber, KJ. Franklyn, JA. McCabe, CJ. Khanim, FL. Bulmer, JN. Whitley,GSJ, et al. The In Vitro Effects OfTriiodotyronine on Epidermal Growth Factor-Induced Trophoblast Function. Journal of Clinical Endocrinology \& Metabolism. Vol 90, no 3, 2005, pp : 16551661.

Chan, SY. Vasilopoulou, E. Kilby, MD. The Role of the Placenta in Thyroid Hormone Delivery to the Fetus.Nature Clinical Practice Endocrinology \& Metabolism.Vol 5, 2009, pp :45-54.

Takeshi, M. Hiroya, M. Matsuto, M. Thyroid Hormone as a Biological Amplifier of DifferentiatiedTrophoblastFuntion in Early Pregnancy. Journal of Clinical Endocrinology \& Metabolisme.Vol 47, 2010,pp:772-774.

Green, AS.Optimal Care of the pregnant woman with thyroid disease . The Journal of Clinical Endocrinology \& Metabolism.Vol 97, 2010, pp : 2619-2622.

Hershman, JM.The Role of Human Chorionic Gonadotropin as a Thyroid Stimulator In Normal Pregnancy. Journal ClinEndocrinolMetabolisme.Vol 93, 2008, pp : 3305-3306.

American Thyroid Association.Thyroid Disease and pregnancy.American Thyroid Association (ATA).Vol 3, no. 2, 2012, pp : 116-225. 
Kilby, MD. Verhaeg, J. Gittoes, N. Somerset, DA. Clark, PMS. Franklyn, JA. Circulating Thyroid Hormone Concentrations and Placental Thyroid Hormone Receptor Expression in Normal Human Pregnancy and Pregnancy Complicated by Intrauterine Growth Restriction (IUGR).Journal of Clinical Endocrinology and Metabolism.Vol 83, 2007,pp : 2964-2971.

Putri, RWY . (2018). Relation of age, number of pregnancies, and history of Spontaneous abortion in pregnant women with the incidence of Spontaneous abortion at AghisnaMedika general hospital, Cilacap Regency. Skripsi. Program StudiKedokteranUmumFakultasKedokteranUniversitasMuhammadiyahsurakarta. Surakarta. 2018.

Negro, R. Schwartz, A. Gismondi, R. Tinelli, A. Mangieri, T. Green, AS.Increased Pregnancy Loss Rate in Thyroid antibody Negative Women with TSH Levels Between 2.5 and 5.0 in The First Trimester of Pregnancy. Journal ClinEndocrinolMetabolisme.Vol 95, no 9, 2010, pp : 44-48

Andrea, R, Grifo, J. Dannof, A. Normal Thyroid Stimulating Hormone (TSH) And Efects Of Stricter TSH Thresholds On Pregnancy Outcomes After In Vitro Fertilization. ObstetricAnd Gynecology. Vol 94, no 7, 2010,pp : 2920-2930

Karakosta, P.Chatzi, L. Bagkeris, E. Daraki, V. Alegakis, D. Castanas, E. et al. First and second trimester reference intervals for Thyroid Hormones During Pregnancy in "Rhea" mother child cohort ,crete, greece. Jornal of Thyroid research.Vol 2011, 2011,pp : 1-12

Benhadi, N. Wiersinga, WM. Reitsma, JB. Vrijkotte, TGM. Bonsel, GJ. Higher Maternal TSH Levels in pregnancy are associated with increased risk for miscarriage, fetal or neonatal death. European Journal of Endocrinology. Vol 160, no 6, 2009, pp : 985-991

Shiao, C. Kristien, B. Optimal Management Of Hypothyroidism, Hypothyroxinaemia, And Euthyroid TPO Antibody Positivity Preconception And In Pregnancy. Clinical Endocrinology.Vol 82, 2015,pp :313-32.

Sieiro, NL. Coeli, CM. Micmacher, E. Mamede S. Nazar, L. Galvaou, D. et all. Influence of Thyroid Autoimmunity and Maternal Age The Risk of Miscarriage. American Journal of Reproductive Immunology. Vol 52, 2009, pp : 312-316

Nambiar, V. Jagtap, VS. Sarathi, V. Lila, AR. Kamalanathan, S. Bandgar, TR. et all. (2011). Prevalence and impact of Thyroid Disorders on Maternal Outcome In Asian-Indian Pregnant Women. Journal Of Thyroid Research. Vol 6, 2011, pp 2971-2979

Hirsch,D. Levy, S. Nadler, V. Kopel, V. et all.Pregnancy outcomes in women with severe Hypothyroidism. Journal of Clinical Endocrinology and Metabolism.Vol 169, 2013, pp : 313-320. ISSN : 0804-4643

De Vivo, A. Alfredo, M. Annamaria, G. et al. Thyroid Function in Women Found to Have Early Pregnancy Loss. Gynecological/Obstetrical Sciences and Reproductive Medicine. 2010, pp :517-520 
Vanes, KN. Lazarus, JH. Chan, SY. Thyroid Function in Pregnancy: Maternal and Fetal Outcomes with Hypothyroidism and Subclinical Thyroid Dysfunction. Fetal and Maternal Medicine Review.2011, pp :179-182

Mandel, SJ. Larsen, PR. Seely, LW. Brent, GA. (2008). Increased Need for Thyroxine during Pregnancy in Women with Primary Hypothyroidism. The New England Journal of Medicine.2008, pp :5315-5319

Weetman, AP. (2008). Management of Thyroid Disorders In Pregnancy. Urology Gynecology and Sexual Health. 2008, pp :30-31

Vissenberg, R. The Influence of Thyroid Disorders on Adverse Pregnancy Outcomes.The Obstetrician \&Gynaecologist.Vol 44, 2016, pp : 134-138. ISBN : 978-94-6299-306-8

Victor, JP. Kuijpens, JL. Van Baar, AL. Verkerk, G. Marteen, M. Thomas, V. et all.Low maternal free thyroxine concentrations during early pregnancy are associated with impaired psychomotor development in infancy. Clinical Endocrinology.Vol 50, 2010, pp :149-155

Nambiar, V. Jagtap, VS. Sarathi, V. Lila, AR. Kamalanathan, S. Bandgar, TR. et all. Prevalence and impact of Thyroid Disorders on Maternal Outcome In Asian-Indian Pregnant Women. Journal Of Thyroid Research. Vol 6, 2011, pp 2971-2979

Jefferys, A. Vandenpump, M. Yasmin, E.Thyroid Disfuntion and Reproductive health. The Obstetrician \&Gynaecologist.Vol 17, 2015, pp : 39-45. doi: 10.1111/tog.12161

Dulay, A.T. Spontaneous Abortion (Miscarriage), The Merck Manuals Online Medical Library. Vol 7, no 4, 2010, pp : 701-709

Andrea, R, Grifo, J. Dannof, A.Normal Thyroid Stimulating Hormone (TSH) And Efects Of Stricter TSH Thresholds On Pregnancy Outcomes After In Vitro Fertilization. ObstetricAnd Gynecology. Vol 94, no 7, 2010, pp : 2920-2930

Griebel, CP. Halvorsen, J. Golemon, TB. and Day, AA. Management of Spontaneous Abortion. American Family Physician. Vol 72, 2005, pp : 160-168

\section{BIOGRAPHY}

YellytaUlsafitri earned his Bachelor's degree fromDepartment of D IV midwife educator, Poltekkespadang In 2007. After his graduation until late 2007 she works in STIKesDharmasrayais a Midwifery lecturer. She is Master's Degree from DepartmentMidwifery Faculty of Medicine, Andalas University, Padang In 2018. YellytaUlsafitri now is a lecturer at STIKesYarsiSumbarBukittinggi. Her research interests are Midwifery, but not limited tomisscarriage. 
Rahmatina, B. Herman is aphysiologylecturer in Faculty of Medicine, Andalas University, Padang. She is Professor at Faculty of Medicine, Andalas University, Padang.

RosfitaRasyid is a public health lecturer in Faculty of Medicine, Andalas University, Padang. 